\title{
Modes of Value Transfer in Chinese Family Business in Malaysia
}

\author{
Su-Hie Ting \\ Faculty of Language and Communication, Universiti Malaysia Sarawak, 94300 Kota Samarahan, Sarawak, MALAYSIA \\ *E-mail for correspondence: shting@unimas.my
}

https://doi.org/10.18034/abr.v10i1.460

\begin{abstract}
The study examined the modes of value transfer from the founder to successors in Chinese family businesses. A case study was conducted involving interview with 19 members of 12 family businesses in business sectors including trading, shipping, timber, newspaper printing, entertainment, and construction. The results showed that value transfer begins even before the founder's descendants start full-time work in the family business, leading to internalization of values. When the founder's descendants begin working in the family business, explicit teaching and modeling of values occur, which reinforces values observed earlier. In some cases, values are reinforced through management policies that document the founder's values and best practices in conducting business. In most cases, the successors are scaffolded into how values guide business decisions when they work full-time in the family business. The findings offer novel information on the modes of value transfer in the Chinese family business.
\end{abstract}

Funding: This work was funded by the Ministry of Education, Malaysia via the Fundamental Research Grant Scheme, Grant No. FRGS/05(37)/845/2012(85)

Key words: values, value transfer, family business, succession, Chinese culture

\section{INTRODUCTION}

Succession problems in a family business often prevent the survival of family business past the third generation (Duh et al., 2009; Kets de Vries, 1993; Morris et al., 1996; Poza, 2010; Ward, 1987). A family business is defined as a business where at least one family member is in a management position, and multiple generations work in the company (Shanker and Astrachan, 1996). One of the factors crucial for continuity in intergenerational transition in family business is the transfer of idiosyncratic resources and tacit knowledge, and values is among these valuable resources. Studies have shown that positive values espoused by the founders are transferred across generations in family business in Western settings. The four common values transferred from founder to successor in family businesses are integrity, commitment, self-confidence and hard work (Arnonoff and Ward, 1995; Astrachan, 1988; Erdem and Baser, 2010; García-Álvarez and López-Sintas, 2006; Goldberg and Wooldridge, 1993; Haugh and McKee, 2003; Malone, 1989; Morris et al., 1996;
Tokarczyk et al., 2007). In Chinese family businesses, the founders also transfer particular values to their successors, such as the importance of trustworthiness (Redding, 2000; Ting, in press) and networking or guanxi (Faure and Tang, 2008; Lee and Chan, 1998; Tsang, 2001), putting family before self (Yan and Sorenson, 2004), diligence (Ting, in press; Weidenbaum, 1996), thrift (Wah, 2001), and self-discipline (Ting, in press).

Socialization is one of the modes of value transfer in family businesses (Dou and Li, 2013; García-Álvarez, López-Sintas and Gonzalvo, 2002; Whatley, 2011). “Brunaker (1996), Kets de Vries (1993) and Corbetta and Montemerlo (1999) have emphasised the founder's role in selecting and conveying to potential successors a set of well-established values as a way of facilitating a successful succession process and ensuring the future growth and success of the firm" (as cited in GarcíaÁlvarez and López-Sintas, 2003, p. 2). However, in the context of succession in family business, value transfer has been understudied compared to the preparation of heirs, 
the relationship among family members, and informal planning and control activities (Morris et al., 1996).

Many successful Chinese businesses are family-owned businesses. Chinese family business presents a unique context to study value transfer because scholars working in this area have argued that there are cultural values that are distinctly Chinese (Dou and Li, 2013; Fan, 2000; Kirby and Fan, 1995; The Chinese Cultural Connection, 1987; Yeung, 2006). Researchers have identified key values transferred from founders to successors in family businesses (Faure and Tang, 2008; Lee and Chan, 1998; Redding, 2000; Ting, in press; Tsang, 2001; Wah, 2001; Weidenbaum, 1996; Yan and Sorenson, 2004). However, little is known about modes of value transfer in Chinese family businesses because there has not been much research on the value transfer process in family business.

The present study examined the modes of value transfer from the founder to successors in Chinese family businesses. In this paper, "founder" refers to the person who first established the business although the nature of the business may have changed over time. "Successor" refers to descendants of the founder who may be the second-, third- or fourth-generation family members.

\section{LITERATURE REVIEW}

\section{Values transferred in family business}

Research indicates that values may make or break the intergenerational transition in family firms, and it is important to research the useful values and the mechanism for the transfer of values. The negative effects of values can be seen in the case of Yeo Hiap Seng in Singapore, where intra-family conflict resulted in a takeover by an outsider. To Fock (2012), Chinese cultural values stood in the way of conflict resolution in Yeo Hiap Seng because nepotism led to the second generation choosing their offspring as the successor despite low competency. In addition, mian zi (pride) prevented the third generation from maintaining the unity of their second generation in Yeo Hiap Seng.

Research has identified some values that are important for the intergenerational transition. Sharma's (2004) review indicates that the most desirable attributes for heirs to have, from the perspective of family firm leaders in Western and Eastern cultures, are integrity and commitment to business. However, from the perspective of heirs, the more the family relationships are characterized by trust, openness, co-operation, respect, and absence of defensiveness, conflict and resentfulness, the easier the transition (Morris et al., 1996). Family business continuity is higher with trust, open lines of communication, and family harmony (Malone, 1989). The communication flow among the family business owners of food and forest products companies is so open that it also involved grandmothers and aunts not involved in the business (Tokarczyk et al., 2007). The informality, flexibility, and mutual respect which characterize the ongoing dialogue enables family business owners to tap into the unique business understanding and acumen acquired from extended exposure to and experience within the family business. Communication and trust are also among the important values in family firms, the others being commitment and human relations (Aronoff and Ward, 1995). Similar findings on the value of trust were obtained by Haugh and McKee (2003) from their study of family firms in the fish processing industry in Scotland, and the other values were a sense of belonging, honesty, loyalty, and respect. Commitment to business, loyalty and trust are important values in a family business in America's Midwest (Astrachan, 1988). In Spain, GarcíaÁlvarez and López-Sintas (2006) found that founders transfer six main values to potential successors, namely, business orientation, hard work, family orientation, autonomy, entrepreneurship and growth. Based on Erdem and Baser (2010), the values transferred from founders to successors of family businesses are both job values (industriousness, commitment, honesty) and family values (trust, justice and patriarchal family relationships).

In a family firm, the overlap between family values and business values sustains the family business commitment (Dyer and Handler, 1994; Nelton, 1991). Putting the family business above personal interest is an important value that sustains intergenerational transition in family business (Yan and Sorenson, 2004). However, Ting's (in press) study of Chinese family businesses in Malaysia showed that prioritizing personal interest over family obligation is a new value that has emerged among the potential successors, causing some of them to choose not to join their father's family business. Whether this is due to the failure of founders to pass on the value of continuing the family business is uncertain, which is why it is important to examine the process of value transfer.

\section{Modes of value transfer in family business}

Successors of family business are socialized into the tacit knowledge and values held by family firm founders through family socialization and business socialization. García-Álvarez, López-Sintas and Gonzalvo's (2002) study in Spain found that the first phase of family socialization includes value transmission (both emotional and cognitive aspects) to the founders' descendants during childhood. The second phase of business socialization takes place when descendants work full time in the family business. Depending on the founder's orientation, García-Álvarez et al. (2002) proposed two models of value transfer. The Founder Homosocial Reproduction Model applies to founders who emphasize group values and business-as-ameans bring their descendants early into the business and train them in every aspect of the business. Early socialization of children into the family business results in the founder and successor having common business 
expertise, business network, and views regarding the family business. The New Leader Development Model applies to founders who emphasize personal realization and business-as-an-end to place their children in managerial positions related to their academic backgrounds, supervised by trusted managers. This results in a weak founder-successor relationship and different points of view on the family business. The New Leader Development Model is congruent with Chirico's (2008) Family Owned Business Knowledge Accumulation Model in which emotional and openness factors are key elements that aid successful transitions (Whatley, 2011). The founder is open to the successor taking academic courses and practical training courses outside the family business, working outside the family business and employing nonfamily members to add to the tacit knowledge acquired from him (Chirico, 2008). For successful transitions, the openness element needs to be coupled with certain emotional factors, which are family relationships working within the family, trust, commitment to the family business, and psychological ownership of the business (Chirico, 2008).

Value transfer in Chinese family businesses is seen as a transfer of guanxi or networks. From their study of six case firms in China, Dou and Li (2013) identified four stages in the transfer of guanxi networks: (1) preheating when the founders share experiences and guanxi philosophy; (2) triggering when the founders create opportunities for the successor to meet their guanxi and give direct guidance during business negotiations or informal gatherings; (3) readjusting in guanxi building and managing when the founders reduce their role in the business; and (4) reconstructing when the successors renew guanxi parties and rebuild network structures. In the context of García-Álvarez et al.'s (2002) model of the socialization process in family business, preheating can happen during the family socialization phase. Still, the other three stages can only take place during the business socialization phase.

"Learning by example" is a form of family socialization that begins as early as childhood. Trevinyo-Rodríguez and Bontis's (2010, p. 429) study of a retail company showed that daily communication among family members has made the potential successors competent in different areas related to the business. Through the socialization, the founder transfers family knowledge to his children, making them more efficient when they join the family business. The wisdom pertains to the family business (e.g., business culture, routines) and close-knit family network (e.g., family traditions), but negative family ties may cause successors to reject any learning concerning the family business. In another study in Singapore, Khoo, Chung, and Guan (1993, p. 19) found that it is important for family members to "talk it out" so that values, and expectations of one another and the business can be shared. Nevertheless, the founders of these Singaporean family businesses also emphasized the lifelong grooming of successors and learning from the bottom of the corporate ladder. Early entry into the family business is also the main finding from Muriithi et al.'s (2016) survey of 52 family business owners and managers in Mombasa City, Kenya. Muriithi et al. (2016) found some cultural differences in grooming: African founders encouraged their successors to acquire soft skills; Indian founders included them early in business strategic development and planning; and the Arabs involved them early in business operations. The business socialization takes place through nurturing and mentoring by the founder to pass on the entrepreneurial values and drive (Ibrahim et al., 2004). According to Tàpies and Fernández Moya (2012), the next-generation family members learn about values through living them, imitating them, and watching and listening to the older generation, but one participant in their study felt that formalizing them in a document is useful.

The present state of knowledge on value transfer in family business is that successors internalize values since childhood (family socialization) and when they enter the family business, they learn by example and sometimes through explicit teaching of values by founders (business socialization). The values are transferred through a lifelong grooming process which involves mentoring, nurturing and scaffolding - apprenticeship in short.

\section{Method OF THE StUdY}

The data were from 12 Chinese family businesses in Sarawak Malaysia. These family businesses had at least one intergenerational transition, which means that at least the second generation had been incorporated into the management of the business. The founders had an immigrant background in that either they or their father had migrated from China to escape economic hardship. They were mainly involved in agricultural activities but moved into trading activities when they had accumulated some capital. The family businesses selected were outstanding in the records of the Chinese Chamber of Commerce of Sarawak, in Malaysia. Some of the family firms had been public-listed at the time of the study. Table 1 shows the age and industry but not the size of the business, market share and customer perception because this information could not be obtained due to confidentiality.

Altogether, 19 participants from the 12 Chinese family businesses were interviewed (6 founders; 13 successors). The sample size in research on family business is usually small because of the unwillingness of entrepreneurs to be interviewed (Chaudhry and Crick, 2004; Harzing et al., 2011). However, the sample size of this study fit into Eisenhardt's (1989) recommendation of four to ten cases to attain theoretical saturation (see Dessi et al., 2014; Erdem and Baser, 2010). 
Table 1: Description of family businesses in the study

\begin{tabular}{|c|c|c|}
\hline $\begin{array}{l}\text { Family } \\
\text { business }\end{array}$ & $\begin{array}{c}\text { Year of } \\
\text { establishment }\end{array}$ & Business history \\
\hline FB1 & \begin{tabular}{|c|}
$1960 \mathrm{~s}$ \\
\end{tabular} & $\begin{array}{l}\text { A Foochow family business based } \\
\text { in Sibu which began with trading } \\
\text { of hardware and building } \\
\text { products and has grown into a } \\
\text { supplier and provider of } \\
\text { engineering products }\end{array}$ \\
\hline FB2 & 1940s & $\begin{array}{l}\text { A Foochow family business based } \\
\text { in Sibu which grew from water } \\
\text { transportation of goods to ship } \\
\text { building and shipping services }\end{array}$ \\
\hline FB3 & $1940 \mathrm{~s}$ & $\begin{array}{l}\text { A Foochow family business based } \\
\text { in Bintulu which began with } \\
\text { sawmilling and logging and has } \\
\text { diversified into upstream and } \\
\text { downstream services of the } \\
\text { timber industry }\end{array}$ \\
\hline FB4 & $1950 \mathrm{~s}$ & $\begin{array}{l}\text { A Foochow family business based } \\
\text { in Sibu which began with fish } \\
\text { products but has since diversified } \\
\text { into construction and shipping }\end{array}$ \\
\hline FB5 & 1920s & $\begin{array}{l}\text { A Teochew family business in Bintulu } \\
\text { which began with sago milling but } \\
\text { later ventured into shipping }\end{array}$ \\
\hline FB6 & 1950s & $\begin{array}{l}\text { A Foochow family business which } \\
\text { originated from a grocery store and } \\
\text { distribution of animal feed in Sibu } \\
\text { has developed into a supermarket } \\
\text { chain in various parts of Malaysia }\end{array}$ \\
\hline FB7 & 1970s & $\begin{array}{l}\text { A Foochow family business in } \\
\text { Sibu which has diversified from } \\
\text { newspaper production to paper } \\
\text { related industries }\end{array}$ \\
\hline FB8 & $1960 s$ & $\begin{array}{l}\text { A Hokkien family business in } \\
\text { Sibu which began with furniture } \\
\text { supplies but is now mainly in the } \\
\text { construction industry }\end{array}$ \\
\hline FB9 & $1960 s$ & $\begin{array}{l}\text { A Foochow family business } \\
\text { operating cinemas and hosting } \\
\text { entertainment shows which began } \\
\text { in Sibu but has now diversified into } \\
\text { construction and real estate }\end{array}$ \\
\hline FB10 & $1960 \mathrm{~s}$ & $\begin{array}{l}\text { A Foochow family business based in } \\
\text { Kuching which manufactures and } \\
\text { markets timber products, and also } \\
\text { engages in property development }\end{array}$ \\
\hline FB11 & 1930s & $\begin{array}{l}\text { A Foochow family business began } \\
\text { as a grocery store in Sibu and is } \\
\text { currently a wholesaler for food } \\
\text { products }\end{array}$ \\
\hline FB12 & 1970s & $\begin{array}{l}\text { A Lui Chew family business } \\
\text { which began with insurance but } \\
\text { has since diversified into } \\
\text { department stores and } \\
\text { gymnasiums based in Kuching }\end{array}$ \\
\hline
\end{tabular}

Note: Foochow, Teochew, Hokkien and Lui Chew are Chinese dialect groups
During the data collection period, eight of the 12 founders had passed away (Family Businesses 1, 2, 5, 7, 8, 10, 11 and 12 ), and the family business is run by their successors. The other four founders had incorporated their children into the management of the firm as directors or CEOs of subsidiary companies. For four of the family businesses (2, $5,6,7)$, two generations were interviewed.

Before the interview, the researcher wrote to the participants, seeking an interview. The purpose of the study, and the guiding interview questions were included in the letter. The main questions were "Did you (your father) emphasize certain values to the family?" and "How was it done?"

Subsequently, the participants were contacted via telephone and email to discuss the interview dates. Semistructured interviews were conducted. Initial interviews lasted 50-90 minutes, but follow-up interviews were shorter (45-60 minutes). The interviews were conducted in Mandarin, Foochow (a Chinese dialect), and English, depending on the preference of the participants. The audio-taped interviews were transcribed in English using Eggins and Slade's (1997) transcription conventions. Contextual information were written down and added to the interview transcripts.

The interview data were analyzed using Rubin and Rubin's (1995) approach in the thematic analysis of interview data. Besides direct answers to the question posed, other parts of the interview transcripts were scrutinized for unprompted information on values. In the initial coding, the researcher used the participants' words for the modes of value transfer, but in later stages of coding, a common term was used. The transcripts were reread to check for negative instances of the patterns to test the validity of the analysis. Through this process, a framework for the mode of value transfer in the Chinese family business was constructed.

\section{RESULTS}

In this section, the Chinese family businesses are referred to FB1 to FB12. The founders are referred to as F1 to F12, while the successors are referred to as S1 to S12. Five modes of value transfer were mentioned by both founders and successors (Figure 1), namely, explicit teaching of values, learning by example, learning through working in the company, teaching through management policy, and formalizing of values.

Firstly, explicit teaching of values may happen during the founders' everyday conversations with their employees and family, regardless of whether they are running the business. Sometimes the children also attended company events where they listened to their father or grandfather giving speeches. For example, S7 said that he listened to his father repeatedly talking about the importance of working hard and being honest until his "ears dropped", 
and this happened at home and in his meetings with employers at various newspaper branches in various parts of Sarawak and Sabah. Similarly, S8 had to "frequently brainwash" his family and employees and remind them not to "cheat people" to build their client's trust in them and the reputation of their construction firm as one with integrity. Another founder (F9) had been instilling positive values and work attitudes in his children and employees through weekly Bible study sessions. For the five participants who mentioned explicit teaching as a mode of value transfer, some highlighted their father talking about values (S1, S7, S10) while others shared how they passed this value to others (S8, F9), showing that explicit teaching of values is common to both founder and successor generations.

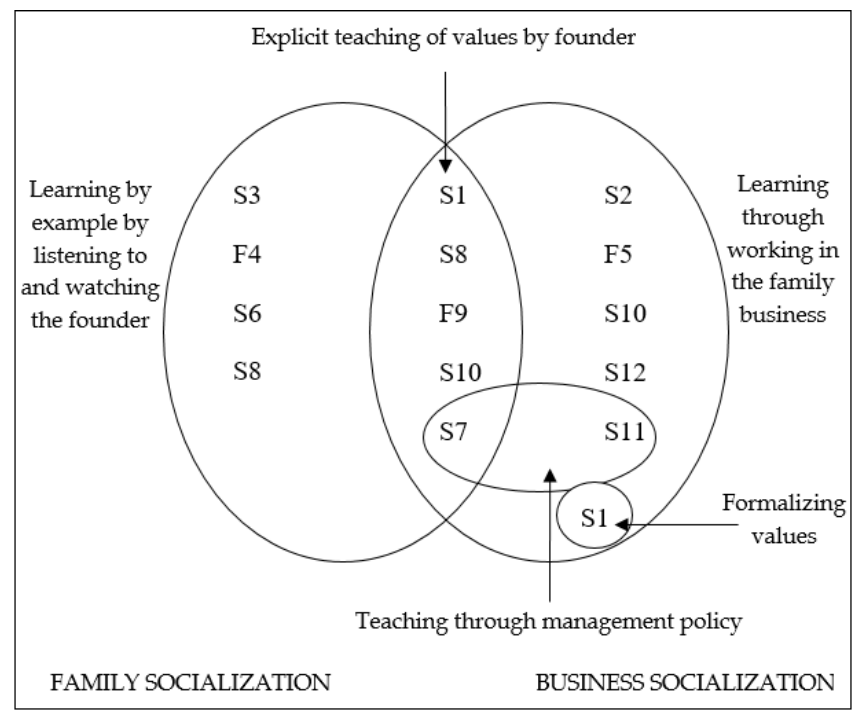

Figure 1: Classification of modes of value transfer in Chinese family businesses

The second mode of value transfer is learning by example (nine out of 12 Chinese family businesses). For years, the potential successors watched their father going about the routine tasks of the business. For instance, S3 said "actually in the younger days, we always go to the factory to have a look, [when we left this town for studies] we come back every year to know what is going on." He left for Singapore to continue his secondary education when he was 14 but before that, he was always in his father's company and factory during weekends and school holidays. He had been watching his father's work attitudes, evident when he said "So you see how he conducts his living, very disciplined." Because of his early immersion into the business, he was able to assume control of the business when he returned after his university education, and his father retired after two or three years after the business transition. S3 said that his sons went through the same experience as him, and they have entered the family business. Learning by example comes under family socialization (García-Álvarez et al., 2002), and it is the first phase of socializing successors into the family business, and value transmission and internalization take place without the successors being aware of it.
The third mode of value transfer is through full-time work in the company, a common practice among the Chinese family business. As an example, S2's second son worked from the bottom rung in the shipyard after completing his university degree: machinery for the first few months; engine and drill bed for the next few months; and went on to wiring. In this way, he mixed with his father's employees at all levels and in all sectors of the shipbuilding business. His four other siblings later entered the family business and took up other portfolios. FB2 is unique because the children had already agreed to take up university degrees relevant to their father's business. The founder's only daughter took up an information technology degree while her brothers specialized in fields of engineering that were relevant to their father's business. Upon graduation, the brothers enrolled in maritime courses because it was important for them to understand the shipping industry. One of them was a qualified captain on international routes, while another was a qualified captain on domestic routes. The outstanding characteristic about FB2 is that the founder put his children to work from the bottom rung, instead of immediately placing them in managerial positions. When the successors work full-time in the family business, they are like apprentices. Business socialization through apprenticeship in the family business enable the successors and founders to develop common business expertise, network and values (García-Álvarez et al., 2002). Some studies (Muriithi et al., 2016) have found that early involvement in the family business is beneficial for continuity, but from their study on Singapore family businesses, Khoo et al. (1993) felt that starting at the bottom of the corporate ladder has its risks because when potential successors make mistakes, they are seen as incompetent and this affects confidence in their ability to manage the family business. Khoo et al. (1993) suggest that successors should be placed on short and definite periods of attachments to familiarize them with the functions of the firm to overcome this problem.

The fourth mode of value transfer is via the implementation of management policy, which took place in two family businesses. S11, who owned a supermarket chain said that he wanted his supervisors and employees in charge of delivery to be committed to doing an accurate stocktaking of goods passing through their hands. To show them that he meant business, he made them pay for missing goods, and he called this method "management by responsibility". Without a punitive system, his employees might not take their responsibility seriously, and his company would lose profit through missing goods every month. Similarly, S7 said his father penalized them to inculcate desired values. He related an incident when his eldest brother left a bag of cash for employees' salary in a boat, and it was lost. His father deducted his brother's salary to the full, and he was without salary for many months. Value transfer via management policy is usually accompanied by negative reinforcement. 
Figure 1 shows that there is an overlap of modes of value transfer because two or more modes can be used simultaneously, or sequentially in different stages of the successor's life. Most of the successors learn by example. When they are children, they observe the founders in action, although they may not understand the full meaning of what is happening. When they grow up, they work in the company. As they work alongside their father, they live out the values, listen to, and watch the founder in action. In half of the family businesses, the founders explicitly talk about values to their successors. The founders can explicitly talk about values before and after their successors enter the business. However, reinforcing values through management policy is distinctly different, and is represented as a subset of learning through working in the family business. Negative reinforcement did not surface in other studies on value transfer in family business. It is more common for founders to overlook successors' mistakes and incompetency, and is one of the reasons for the failure of family businesses such as Yeo Hiap Seng (Fock, 2012).

Finally, an unusual mode of value transfer is formalizing the values which were mentioned by one successor. S1 engaged a consultant from Singapore in 2012 to identify the values of his father so that the document could be used for human resource development. S1 said that the values were later built into various areas in their business so that they could be passed on to the future generations of the family and employees. One founder in Tàpies and Fernández Moya's (2012) study also said that formalizing values in a document is useful. Formalizing the values makes the value transfer more tangible, and the values can be passed on to more employees. In informal modes of value transfer, only employees closest to the family members running the business can acquire the values. Incorporation of key values into the management policy of the family business ensures compliance, whether or not the family members and employees believe in the values. Over time, behavioral compliance may develop into beliefs. However, for the value transfer to be effective, the CEOs and other leaders of the family business must also be seen to live out the values.

\section{DISCUSSION AND CONCLUSION}

This study shows the interdependence of modes of value transfer from the founder of Chinese family businesses to their successors. The successors learn values by example, from working full-time in the business, through explicit teaching of values by the founder, and through the implementation of management policies. Learning by example is a common mode of value transfer that begins during family socialization, also reportedby TrevinyoRodríguez and Bontis (2010). Learning by example is referred to as grooming by Khoo et al. (1993) and Muriithi et al. (2016). The findings suggest that for successful intergenerational transition, potential successors need to be groomed from childhood so that they may prioritize the family business over personal interest in career decisions. To ensure that value transfer takes place, founders explicitly teach their values to successors. Explicit teaching of values is not unique to this study because "talking it out" is important to Singaporean Chinese family businesses (Khoo et al., 1993), concurring with past research on the importance of open communication (Malone, 1989; Tokarczyk et al., 2007). The value transfer continues when the successors get involved in the ownership and control of the business. For Chinese family businesses, this is the time when the value of guanxi is transferred (Dou \& Li, 2013). Two new modes of value transfer were found in the present study that is, formalizing of the founder's values and implementation through management policies. While formalizing may be useful for wider dissemination of values, it may not lead to the changes in family and business values. Nevertheless, in view of how vital value transfer is to smooth generational transition and survival of family business, it is worth for founders of family businesses to consider all modes of value transfer so that invaluable idiosyncratic resources and tacit knowledge are passed on to the next generation. Future studies should investigate the impact of these newer modes of value transfer on intergenerational transfer of values in family businesses to attain a better understanding of the fundamentals of generational succession, particularly the means to transfer the passion to continue operating the family business to potential successors.

\section{REFERENCES}

Aronoff, C.E., and Ward, J.L. 2001. Family business values: How to assure a legacy of continuity and success (No. 12). Georgia: Family Enterprise Publisher.

Astrachan, J.H. 1988. Family firm and community culture. Family Business Review, 1(2), pp. 165-189.

Brunaker, S. 1996. Introducing second generation family members into the family operated business. Doctoral Dissertation. Swedish University of Agricultural Sciences, Uppsala.

Chaudhry, S., and Crick, D. 2004. A case history of a 'successful' Asian entrepreneur in the UK: Sir G.K. Noon. International Journal of Management Cases, 7, pp. 5-12.

Chirico, F. 2008. Knowledge accumulation in family firms evidence from four case studies. International Small Business Journal, 26(4), pp. 433-462.

Corbetta, G., and Montemerlo, D. 1999. Ownership, governance, andmanagement issues in small and medium-size family business: A comparison of Italy and the United States. Family Business Review, 12(4), pp. 361-374.

Crick, D., and Chaudhry, S. 2013. An exploratory study of UK based, family-owned, Asian firms' motives for internationalising. Journal of Small Business and Enterprise Development, 20(3), pp. 526-547.

Dessi, C., Ng, W., Floris, M., and Cabras, S. 2014. How small family-owned businesses may compete with retail superstores: Tacit knowledge and perceptive concordance among owner-managers and customers. Journal of Small Business and Enterprise Development, 21(4), pp. 668-689. 
Dose, J.J. 1997. Work values: An integrative framework and illustrative application to organizational socialization. Journal of Occupational and Organizational Psychology, 70(3), pp. 219-240.

Dou, J., and Li, S. 2013. The succession process in Chinese family firms: A guanxi perspective. Asia Pacific Journal of Management, 30(3), pp. 893-917.

Duh, M., Tominic, P., and Rebernik, M. 2009. Growth ambitions and succession solutions in family businesses. Journal of Small Business and Enterprise Development, 16(2), pp. 256-269.

Dyer, W.G., and Handler, W. 1994. Entrepreneurship and family business: Exploring the connections. Entrepreneurship Theory and Practice, 19(1), pp. 71-84.

Eggins, S., and Slade, D. 1997. Analyzing casual conversation. London: Cassell Academic.

Eisenhardt, K.M. 1989. Building theories from case study research. Academy of Management Review, 14(4), pp. 532-550.

Erdem, F., and Gül Baser, G. 2010. Family and business values of regional family firms: a qualitative research. International Journal of Islamic and Middle Eastern Finance and Management, 3(1), pp. 47-64.

Fan, Y. 2000. A classification of Chinese culture. Cross Cultural Management, 7(2), 3-10.

Faure, G.O., and Fang, T. 2008. Changing Chinese values: Keeping up with paradoxes. International Business Review, 17, pp. 194-207.

Fock, S.T. 1998. The impact of family conflicts on the development of the Chinese entrepreneurially managed family business: The Yeo Hiap Seng Case in Singapore. Journal of Small Business $\mathcal{E}$ Entrepreneurship, 15(2), pp. 88-102.

Garcia Alvarez, E., and López Sintas, J. 2003. Coherence between values and successor socialization: Facilitating family business continuity. IESE Working Paper No. D/512. Available at SSRN: https://ssrn.com/abstract $=459202$ or http://dx.doi.org/10.2139/ssrn.459202

García-Álvarez, E., and López-Sintas, J. 2006. Foundersuccessor's transition: A model of coherent value transmission paths. In P.Z. Poutziouris, K.X. Smyrnios, \& S.B. Klein (Eds.), A handbook of research on family business (pp. 237-252). Cheltenham, UK: Elgar Publishing Ltd.

García-Álvarez, E., López-Sintas, J., and Gonzalvo, P. S. 2002. Socialization patterns of successors in first-to secondgeneration family businesses. Family Business Review, 15(3), pp. 189-203.

Harzing, A.W., Köster, K., and Magner, U. 2011. Babel in business: The language barrier and its solutions in the HQ-subsidiary relationship. Journal of World Business, 46(3), pp. 279-287.

Haugh, H., and McKee, L. 2003. "It's just like a family" - shared values in the family firm. Community, Work E Family, 6(2), pp. 151-148.

Hitchcock, M., and Wesner, S. 2009. Vietnamese values, networks and family businesses in London. Asia Pacific Business Review, 15(2), pp. 265-282.

Ibrahim, A.B., McGuire, J., Soufani, K., and Poutziouris, P. 2004. Patterns in strategy formation in a family firm. International Journal of Entrepreneurial Behavior E Research, 10(1/2), pp. $127-140$.
Kets de Vries, M.F.R. 1993. The dynamics of family controlled firms: The good news and the bad news. Organizational Dynamics, 21(3), pp. 59-71.

Khoo, A.T., Chung, S., \& Guan, C.T.K. 1993. Succession planning in family business. Journal of Small Business $\mathcal{E}$ Entrepreneurship, 10(3), pp. 15-32.

Kirby, D.A., and Fan, Y. 1995. Chinese cultural values and entrepreneurship: A preliminary consideration. Journal of Enterprising Culture, 3(3), pp. 245-260.

Lee, J., and Chan, J. 1998. Chinese entrepreneurship: A study in Singapore. Journal of Management Development, 17(2), pp. 131-141.

Lin, C. 2008. Demystifying the chameleonic nature of Chinese leadership. Journal of Leadership $\mathcal{E}$ Organizational Studies, 14(4), pp. 303-321.

Malone, S.C. 1989. Selected correlates of business continuity planning in the family business. Family Business Review, 2(4), pp. 341-353.

Morris, M.H., Williams, R.W., and Nel, D. 1996. Factors influencing family business succession. International Journal of Entrepreneurial Behaviour \& Research, 2(3), pp. 68-81.

Muriithi, S.M., Waithira, V., and Wachira, M. 2016. Family business founders' influence on future survival of family businesses. International Journal of Economics, Commerce and Management, IV (1), pp. 560-575.

Nelton, S. 1991. Ten keys to success in family business. Nations Business, 79, pp. 44-45.

Poza, E.J. 2010. Family business. Mason, Ohio: South-Western Cengage learning.

Redding, G. 2000. What is Chinese about Chinese family business? And how much is family and how much is business? In H. Yeung \& K. Olds (Eds), Globalization of Chinese business firms (pp. 31-54). Palgrave Macmillan UK.

Rubin, H.J., and Rubin, I.S. 1995. Qualitative interviewing: The art of hearing data. California: Sage Publications.

Seah, M., Hsieh, M.H., and Weng, P.D. 2010. A case analysis of Savecom: The role of indigenous leadership in implementing a business intelligence system. International Journal of Information Management, 30(4), pp. 368-373.

Shanker, M.C., and Astrachan, J.H. 1996. Myths and realities: Family businesses' contribution to the US economy-A framework for assessing family business statistics. Family Business Review, 9(2), pp. 107-119.

Sharma, P. 2004. An overview of the field of family business studies: Current status and directions for the future. Family Business Review, XVII (1), pp. 1-36.

Tàpies, J., and Fernández Moya, M. 2012. Values and longevity in family business: Evidence from a crosscultural analysis. Journal of Family Business Management, 2(2), pp. 130-146.

The Chinese Culture Connection. 1987. Chinese values and the search for culture-free dimension of culture. Journal of CrossCultural Psychology, 18(2), pp. 143-164.

Ting, S.H. in press. Values in family businesses owned by Chinese diaspora in Sarawak, Malaysia. International Journal of Chinese Culture and Management, 5. 
Tokarczyk, J., Hansen, E., Green, M., and Down, J. 2007. A resource-based view and Market Orientation Theory examination of the role of "familiness" in family business Success. Family Business Review, 20(1), pp. 17-31.

Trevinyo-Rodríguez, N.R., and Bontis, N. 2010. Family ties and emotions: a missing piece in the knowledge transfer puzzle. Journal of Small Business and Enterprise Development, 17(3), pp. 418-436.

Tsang, D. 2007. Leadership, national culture and performance management in the Chinese software industry. International Journal of Productivity and Performance Management, 56(4), pp. 270-284.

Tsang, E.W.K. 2001. Internationalizing the family firm: A case study of a Chinese family business. Journal of Small Business Management, 39(1), pp. 88-94.
Wah, S.S. 2001. Chinese cultural values and their implication to Chinese management. Singapore Management Review, 23(2), pp. 75-83.

Ward, J.I. 1987. Keeping the family business healthy. San Francisco, CA: Jossey-Bass.

Weidenbaum, M. 1996. The Chinese family business enterprise. California Management Review, 38(4), pp. 141-156.

Whatley, L. 2011. A new model for family owned business succession. Organization Development Journal, 29(4), pp. 21-32.

Yan, J., and Sorenson, R. L. 2004. The influence of Confucian ideology on conflict in Chinese family business. International Journal of Cross Cultural Management, 4(1), pp. 5-17.

Yeung, H.W.C. 2006. Change and continuity in Southeast Asian ethnic Chinese business. Asia Pacific Journal of Management, 23, pp. 229-254.

$--0-$

Online Archive: https://abc.us.org/ojs/index.php/abr/issue/archive 